\title{
Faktor penyebab perdagangan orang di wilayah hukum Polres Malang Kota
}

\section{Factors of causes of trafficking people in the Malang City Police area}

\author{
Yuliana Plantika \\ Program Studi Magister Kajian Ilmu Kepolisian, Sekolah Pascasarjana Universitas Airlangga \\ Surabaya, 60286, Jawa Timur, Indonesia \\ E-mail: yuliana_plantika@yahoo.com
}

\begin{abstract}
Abstrak
Perdagangan anak telah berkembang dalam bentuk jaringan kejahatan terorganisir dan tidak terorganisir, baik antar negara maupun domestik, sehingga menjadi ancaman bagi masyarakat. Perdagangan anak terjadi di berbagai daerah termasuk di Kota Malang. Tujuan dari penelitian ini adalah untuk menganalisis dan memeriksa faktor-faktor korban perdagangan anak di wilayah hukum Kepolisian Kota Malang. Dalam penelitian ini pendekatan yang digunakan adalah kualitatif dengan menggunakan perundang-undangan, pendekatan konsep dan studi kasus. Jenis penelitian ini adalah penelitian yuridis empiris. Hasil penelitian ini menunjukan bahwa faktor-faktor yang mendasari terjadinya perdagangan anak adalah faktor ekonomi, faktor lingkungan, faktor pendidikan, faktor sosial budaya, tidak adanya kesetaraan gender dan faktor penegakan hukum.
\end{abstract}

Kata Kunci: perdagangan anak; penegakan hukum; polisi; kejahatan

\begin{abstract}
Child trafficking itself has developed in the form of organized and unorganized crime networks, both between countries and domestically, so that it becomes a threat to society. Trafficking of children occurs in many areas, including in the city of Malang. The purpose of this study was to analyze and examine the factors of child trafficking victims in the Malang City Police jurisdiction. In this study, discussing what is used is qualitative using invitations, discussing concepts and case studies while this type of research is empirical juridical research. The results of this study indicate the factors underlying child trafficking are economic factors, environmental factors, educational factors, socio-cultural factors, do not have gender equality and law enforcement factors.
\end{abstract}

Keywords: child trafficking; law enforcement; police; crime

\section{Pendahuluan}

Masalah perdagangan manusia (human trafficking) bukan lagi hal yang baru, tetapi sudah menjadi masalah nasional dan internasional yang berlarut-larut, yang sampai saat ini belum dapat diatasi secara tepat, baik oleh pemerintah setiap negara, maupun oleh organisasi-organisasi internasional yang berwenang dalam menangani masalah perdagangan manusia tersebut (Makarao 2014; Wulandari \& Wicaksono 2014; Sanchez \& Stark 2014; Winterdyk \& Reichel 2010; Crane \& Moreno 2011; McClain \& Garrity 2011). Lemahnya penjagaan dan keamanan daerah perbatasan menjadikan faktor utama perdagangan manusia sehingga dengan mudah seseorang dapat melakukan transaksi perdagangan tersebut (Takariawan \& Putri 2018; Daud \& Supoyono 2019).

Dengan dikeluarkannya Undang-Undang Nomor 35 Tahun 2014 tentang Perlindungan Anak, diharapkan adanya kejelasan tentang batasan bagaimana anak dikatakan sebagai pekerja atau bukan. Batasan tersebut akan membuat permasalahan pekerja anak di Indonesia bisa diminimalisir dan bagi yang mengeksplotasi anak dengan maksud menguntungkan diri sendiri atau orang lain dapat dipidana. Hal tersebut diatur dalam pasal 88 Undang-Undang No. 35 Tahun 2014 tentang Perlindungan Anak. Di sisi lain masih banyak anak-anak di Indonesia yang rentan terhadap kekerasan, baik dilakukan oleh orang tua, teman ataupun orang yang lebih dewasa (Reese - Weber \& Smith 2010). Kekerasan yang dialami oleh anak-anak bisa bersifat fisik maupun non fisik termasuk pelecehan seksual terhadap 
anak-anak dan perempuan yang tinggal di daerah konflik atau daerah bekas bencana. Pasal 1 angka 2 Undang-Undang No. 35 Tahun 2014 tentang Perlindungan Anak, menjelaskan mengenai pengertian dari perlindungan anak adalah segala kegiatan untuk menjamin dan melindungi anak dan hak-haknya agar dapat hidup, tumbuh, berkembang, dan berpartisipasi, secara optimal sesuai dengan harkat dan martabat kemanusiaan, serta mendapat perlindungan dari kekerasan dan diskriminasi.

Pengingkaran terhadap kemuliaan hak asasi seorang anak akan terjadi apabila ada seseorang yang tidak lagi memandang seorang anak sebagai sebuah subyek yang sama dengan dirinya, akan tetapi lebih pada sebagai sebuah obyek yang bisa diperjualbelikan demi keuntungan pribadi. Sementara itu, bisnis perdagangan orang saat ini banyak menjerat anak. Bisnis seperti ini merupakan tindakan yang bertentangan dengan harkat dan martabat manusia dan melanggar hak asasi manusia (Santoso \& Zulfa 2005). Perdagangan anak sendiri sebenarnya telah meluas dalam bentuk jaringan kejahatan yang terorganisasi dan tidak terorganisasi, baik bersifat antarnegara maupun dalam negeri, sehingga menjadi ancaman terhadap masyarakat, bangsa, dan negara, serta terhadap norma-norma kehidupan yang dilandasi penghormatan terhadap hak asasi manusia (Abdullah 2017).

Kasus perdagangan anak juga terjadi di Kota Malang. Dalam kurun waktu 3 (tiga) tahun, perdagangan anak yang terjadi di Kota Malang sebanyak 43 kasus, di mana pada tahun 2018 mencapai 19 kasus. Dalam kasus perdagangan anak perempuan, pelaku terbagi pada pelaku perekrutan (mengajak, menampung atau membawa korban), pengiriman (mengangkut, melabuhkan atau memberangkatkan korban), pelaku penyerahterimaan (menerima, mengalihkan atau memindahtangankan korban). Selain itu, dalam lingkup hubungan antara majikan dan pekerja, dapat juga dikategorikan sebagai sebagai pelaku ketika seorang majikan menempatkan pekerjanya dalam kondisi eksploitatif. Kondisi yang sering terjadi adalah tidak membayar gaji, menyekap pekerja, melakukan kekerasan fisik atau seksual, memaksa untuk terus bekerja, atau menjerat pekerja dalam lilitan utang.

Negara menjamin anak-anak dalam perundang-undangan yang mengatur mengenai hak anak. Hak anak adalah bagian dari hak asasi manusia yang wajib dijamin dilindungi, dan dipenuhi oleh orang tua, keluarga, masyarakat, pemerintah, dan negara. Setiap anak berhak atas perlindungan dari tindak kekerasan secara fisik maupun mental dan diskriminasi serta hak sipil dan kebebasan. Menurut Undang-Undang Nomor 23 Tahun 2002 tentang perlindungan anak, hak-hak anak diatur dalam Pasal 4 sampai Pasal 18 dan pada Pasal 19 telah diatur tentang kewajiban anak. Hak-hak anak dalam proses peradilan pidana merupakan suatu hasil interaksi yang saling terkait dan mempengaruhi dengan yang lainnya. Aspek mental, fisik, sosial, dan ekonomi merupakan faktor yang harus ikut diperhatikan dalam pengembangan hak-hak. Untuk mendapatkan suatu keadilan diperlukan adanya keseimbangan antara hak dan kewajiban.

Tetapi yang sekiranya perlu untuk digarisbawahi adalah dalam hal memperlakukan anak harus memperhatikan kondisi, fisik dan mental, keadaan sosial serta usia dimana pada tiap tingkatan usia anak mempunyai kemampuan yang berbeda-beda. Kepastian hukum perlu diusahakan demi kelangsungan kegiatan perlindungan anak dan mencegah terjadinya penyelewengan yang membawa negatif dalam pelaksanaan perlindungan hukum (Nashriana 2011).

Di samping itu, hak anak sebagai korban salah satunya mendapatkan perlindungan khusus dalam siatuasi dan kondisi tertentu untuk mendapatkan jaminan rasa aman terhadap ancaman yang membahayakan diri dan jiwa dalam tumbuh kembangnya. Menurut Pasal 2 Peraturan Pemerintah Republik Indonesia Nomor 43 Tahun 2017 tentang Pelaksanaan Restitusi bagi Anak yang Menjadi Korban Tindak Pidana, menjelaskan bahwa setiap anak yang menjadi korban tindak pidana berhak memperoleh restitusi. Anak yang berhak mendapat restitusi atau ganti rugi yaitu: a) anak yang berhadapan dengan hukum; b) dieksploitasi secara ekonomi dan/ atau seksual; c) menjadi korban pornografi; d) korban penculikan, penjualan, dan/atau perdagangan; e) korban kekerasan fisik dan/ atau psikis; dan f) korban kejahatan seksual.

Sebagai korban, anak memerlukan perlindungan, yaitu segala kegiatan untuk menjamin dan melindungi anak dan hak-haknya agar dapat hidup, tumbuh, berkembang, dan berpatisipasi, secara 
optimal sesuai dengan harkat dan martabat kemanusiaan, serta mendapat perlindungan dari kekerasan dan diskriminasi (Undang-Undang Nomor 23 Tahun 2002 tentang Perlindungan Anak Pasal 1 Ayat 2). Perlindungan anak di Indonesia berarti melindungi potensi sumber daya insani dan membangun manusia Indonesia seutuhnya, menuju masyarakat yang adil dan makmur, materiil spiritual berdasarkan Pancasila dan Undang-Undang 1945 (Nashriana 2011).

Undang-Undang Nomor 23 Tahun 2002 tentang Perlindungan Anak menegaskan bahwa pertanggung jawaban orang tua, keluarga, masyarakat, pemerintah dan negara merupakan rangkaian kegiatan yang dilaksanakan secara terus-menerus demi terlindunginya hak-hak anak. Upaya perlindungan anak perlu dilaksanakan sedini mungkin, yaitu sejak dari janin dalam kandungan sampai anak berumur 18 (delapan belas) tahun. Undang-Undang Nomor 23 Tahun 2002 tentang Perlindungan Anak meletakkan kewajiban memberikan perlindungan kepada anak berdasarkan asas-asas yaitu a) non-diskriminasi; b) kepentingan yang terbaik bagi anak; c) hak untuk hidup, kelangsungan hidup, dan perkembangan; dan d) penghargaan terhadap pendapat anak.

Istilah perdagangan orang menurut Undang-Undang Republik Indonesia Nomor 21 Tahun 2007 tentang Pemberantasan Tindak Pidana Perdagangan Orang Pasal 1 ayat (1), (7), dan (8) yang dimaksud dengan: (1) Perdagangan orang adalah tindakan perekrutan, pengangkutan, penampungan, pengiriman, pemindahan, atau penerimaan seseorang dengan ancaman kekerasan, penggunaan kekerasan, penculikan, penyekapan, pemalsuan, penipuan, penyalahgunaan kekuasaan atau posisi rentan, penjeratan utang atau memberi bayaran atau manfaat, sehingga memperoleh persetujuan dari orang yang memegang kendali atas orang lain tersebut, baik yang dilakukan di dalam negara maupun antar negara, untuk tujuan eksploitasi atau mengakibatkan orang tereksploitasi; (7) Eksploitasi adalah tindakan dengan atau tanpa persetujuan korban yang meliputi tetapi tidak terbatas pada pelacuran, kerja atau pelayanan paksa, perbudakan atau praktik serupa dengan perbudakan atau praktik serupa dengan perbudakan, penindasan, pemerasan, pemanfaatan fisik, seksual, organ reproduksi, atau secara melawan hukum memindahkan atau mentransplantasi organ dan/atau jaringan tubuh atau memanfaatkan tenaga atau kemampuan seseorang oleh pihak lain untuk mendapatkan keuntungan baik materiil maupun immateriil; (8) Eksploitasi seksual adalah segala bentuk pemanfaatan organ tubuh seksual atau organ tubuh lain dari korban untuk mendapatkan keuntungan, termasuk tetapi tidak terbatas pada semua kegiatan pelacuran dan pencabulan.

\section{Metode Penelitian}

Jenis penelitian ini adalah penelitian yuridis empiris, berupa analisis permasalahan dilakukan dengan cara memadukan bahan-bahan hukum, baik primer yang diperoleh di lapangan maupun data sekunder. Pendekatan masalah yang digunakan meliputi pendekatan perundang-undangan, pendekatan konsep dan studi kasus. Pendekatan perundang-undangan yaitu dengan meneliti perundang-undangan yang terkait dengan isu hukum yang diteliti yaitu tindak pidana perdagangan orang (Yin 2002).

Sumber data atau informasi meliputi data primer dan data sekunder. Data primer adalah data yang diperoleh secara mentah kemudian di analisis lebih lanjut, berasal dari masyarakat secara langsung atau aparat penegak hukum yang berhubungan dengan penelitian ini. Sedangkan data sekunder adalah data yang diperoleh melalui studi kepustakaan dengan mempelajari literatur, tulisan ilmiah, peraturan perundang-undangan, serta dokumen yang diperoleh instansi yang terkait dengan obyek penelitian dan permasalahan yang diangkat.

Sesuai jenis penelitian dan data yang dikumpulkan penelitian ini menggunakan analisa kualitatif, prossesnya adalah sebagai berikut: (1) Penelaahan, yaitu mengedit data secara teliti untuk menemukan keabsahan data, untuk menghindari terjadinya kesalahan data yang dikumpulkan; (2) Klasifikasi, yaitu mengumpulkan data yang telah didapat berdasarkan pokok bahasan masing-masing untuk menghindari kesalahan pengelompokan data; (3) Pengorganisasian, yaitu menyusun data yang dikumpulkan sesuai pengelompokan, agar tidak terjadi kesalahan tempat dan sesuai dengan sistimatika bahasan (Soekanto, 1986). 
Data yang sudah diolah tersebut kemudian dianalisis secara kualitatif, yaitu memberikan arti dan menginterpretasikan pada setiap data yang telah diolah kemudian diuraikan dalam bentuk uraian kalimat secara sistimatis dan logis untuk memudahkan penarikan kesimpulan. Penarikan kesimpulan dilakukan dengan cara deduksi, yaitu dari hal-hal yang bersifat umum kemudian disimpulkan secara khusus terhadap permasalahan yang diteliti.

\section{Hasil dan Pembahasan}

\section{Faktor-faktor yang melatarbelakangi terjadinya perdagangan anak di wilayah Hukum Polres Malang Kota}

\section{Faktor ekonomi}

Faktor ekonomi menjadi penyebab terjadinya perdagangan manusia yang dilatarbelakangi kemiskinan dan lapangan kerja yang tidak ada atau tidak memadai dengan besarnya jumlah penduduk, sehingga kedua hal ini yang menyebabkan seseorang untuk melakukan sesuatu, yaitu mencari pekerjaan meskipun harus keluar dari daerah asalnya dengan resiko yang tidak sedikit.

Hal ini sesuai dengan pernyataan yang disampaikan oleh informan Y sebagai korban perdagangan anak, wawancara 7 Oktober 2019:

"Keluarga saya banyak di rumah, saya sendiri saja yang bekerja. Jadi perlu uang banyak. Karena di Malang sekarang ini susah dapat kerja, jadi saya coba kerja di luar daerah, orang tua juga setuju, karena lulusan SMK susah dapat kerja" (informan Y).

"Sekarang apa-apa mahal, kerja saya tidak cukup untuk makan sehari-hari, jadi saya suruh anak saya ngamen di perempatan Kaliurang, ya 20.000 untuk beli rokok saya" (informan $\mathrm{H}$ ).

Pernyataan itu dapat diartikan jika faktor ekonomi yakni terkait dengan pemenuhan kebutuhan seharihari sangat mempengaruhi keputusan masyarakat untuk mempekerjakaan anak sebagai pengamen.

Adanya Departemen Tenaga kerja di Kota Malang ini tidak banyak membawa kemudahan masyarakat untuk mendapatkan pekerjaan yang sesuai dan yang diinginkan. Pasalnya, administratif yang rumit dan berbelit, membuat masyarakat akhirnya mencoba mencari alternatif lain yang lebih mudah dan lebih menjanjikan, terlebih lagi untuk anak yang baru lulus SMK atau SMA yang maish belum memiliki pengalaman. Hal ini kemudian menjadi celah dan dimanfaatkan dengan cara yang salah oleh oknum-oknum tertentu. Melihat peluang dimana kelemahan masyarakat dalam ekonomi, ditambah lagi badan milik pemerintah belum mampu mengupayakan pelayanan yang makismal, maka oknum tersebut dengan leluasa membuat peluang menggiurkan dengan iming-iming kesejahteraan yang meningkat untuk masyarakat yang membutuhkan pekerjaan demi menutupi kebutuhan ekonominya. Oknum-oknum ini secara berani mengirim orang yang membutuhkan pekerjaan ke luar daerah, bahkan dengan dokumen yang tidak lengkap.

"Kami menangkap seorang tersangka, dengan modus mendirikan sebuah yayasan, namun tidak resmi. Ia mengirimkan orang untuk dipekerjakan sebagai pembantu rumah tangga, tanpa dilengkapi surat dan dokumen resmi lainnya. Ini jelas saja menyalahi hukum tentang TKI yang diatur dalam Undang-Undang" (Informan J).

"Salah seorang yang hendak dikirim tersangka ke Batam, sebagai Pembantu Rumah Tangga, KTP yang ditunjukkannya tidak pernah diterbitkan oleh Dinas Kependudukan dan pencatatan Sipil Kota Malang. Karena setelah ahli melakukan pengecekan pada data Base Kependudukan untuk KTP tersebut tidak terdaftar atau terdata pada Dinas Kependudukan dan Pencacatan Sipil Kota Malang" (Informan YR).

Kedua pernyataan tersebut dapat diartikan bahwa kemudian didapati modus pengiriman tenaga kerja ke luar daerah tanpa kelengkapan berkas serta dokumen resmi dari pemerintah. Bahkan diduga, 
yayasan penyalur tenaga kerja tersebut menyalahgunakan wewenang yang diberikan oleh Dinas Sosial, di mana pada waktu mendaftar yayasan milik tersangka terdaftar sebagai yayasan yang bergerak di bidang kegiatan pelayanan dan rehabilitasi sosial penyandang cacat, pemberdayaan fakir miskin dan penyantunan lansia dan anak terlantar di luar panti. Namun, faktanya hal tersebut disalahgunakan sebagai modus perdagangan anak dengan faktor ekonomi sebagai pencetusnya.

\title{
Faktor lingkungan
}

Perhatian lingkungan yang kurang sehingga menyebabkan si anak tidak mendapatkan perhatian dan melakukan hal-hal yang salah serta dimanfaatkan oleh para pelaku perdagangan orang.

\begin{abstract}
"Anak yang dipekerjakan sebagai pekerja paksa atau selayaknya budak, nyatanya juga bisa karena faktor lingkungan, malah ada orang tua yang sengaja menjadikan anaknya peminta-minta atau pengamen untuk sekadar beli rokok, sementara orang tua sendiri hanya di rumah, anaknya baru SMP dan SD, padahal anak segitu seharusnya sekolah. Ya, bagi lingkungan situ kadang ada yang menganggapnya biasa, ini berarti kesadaran mengenai hak anak dan perlindungan anak masih terabaikan" (informan F).
\end{abstract}

Berdasarkan pernyataan tersebut, maka dapat diartikan bahwa karena perhatian lingkungan yang kurang sehingga menyebabkan si anak tidak mendapatkan perhatian dan melakukan hal-hal yang salah serta dimanfaatkan oleh para pelaku perdagangan anak, bahkan oleh orang tua kandung sendiri.

\section{Faktor pendidikan}

Faktor pendidikan juga merupakan faktor penyebab terjadinya perdagangan anak, karena semakin rendahnya pendidikan seseorang, semakin mudah untuk dipengaruhi oleh para pedagang anak. Maka dari itu sedikit banyaknya pendidikan biasanya mempengaruhi seseorang untuk mendapatkan pekerjaan.

\footnotetext{
"Ya, namanya anak lulusan SMP dan SMA/SMK, ini pasti kan ya bingung sekarang cari kerja dianggap susah, jadi kalau ada tawaran gaji tinggi, pasti mau, padahal belum punya pengalaman, mereka akhirnya tidak tahu kalau dikerjakan secara paksa" (informan TN).
}

Sehingga, anak seharusnya mendapatkan hak-hak yang layak mengenai pengetahuan dan keterampilan yang bisa diaplikasikan ke kehidupan sehari-hari mereka dalam pencaharian uang. Hal ini sesuai dengan hak untuk tumbuh berkembang.

\section{Faktor sosial (kemiskinan)}

Memiliki penghidupan yang kurang layak dan tidak sejahtera dapat menyebabkan keluarga mudah terpengaruh mencari cara apa saja memperbaiki perekonomian keluarganya. Oleh karena itu, penduduk yang miskin mungkin akan lebih rentan terhadap perdagangan orang, tidak hanya karena lebih sedikitnya pilihan yang tersedia utuk mencari nafkah, tetapi juga karena mereka memegang kekuasaan sosial yang lebih kecil, sehingga mereka tidak mempunyai terlalu banyak akses untuk memperoleh bantuan dan ganti rugi. Meskipun bukan merupakan satu-satunya faktor bahwa kemiskinan penyebab kerentanan perdagangan orang.

Di samping itu, kemiskinan juga terdapat pada migran, di mana proses migrasi ini merupakan bentuk migrasi yang dilakukan dalam bentuk tekanan, sebab dalam praktiknya mereka direkrut melalui berbagai bentuk modus penipuan, termasuk melalui perkawinan untuk selanjutnya di bawa ke negara lain dengan tujuan diperdagangkan secara paksa dan biasanya disertai ancaman kekerasan. Meskipun kegiatan migrasi ini merupakan hak asasi manusia, yaitu setiap orang mempunyai hak untuk berpindah tempat dari satu daerah ke daerah lainnya untuk mencoba pengalaman hidup yang baru maupun untuk memperoleh kehidupan yang lebih baik. 


\title{
Ketidaksetaraan gender
}

Adanya ketidaksetaraan relasi antara laki-laki dan perempuan yang membuat perempuan terpojok dan terjebak pada persoalan perdagangan orang. Ini terjadi pada perempuan yang mengalami perkosaan dan biasanya sikap atau respon masyarakat umumnya tidak berpihak pada mereka. Perlakuan masyarakat itu mendorong perempuan memasuki dunia eksploitasi seksual komersial. Sebenarnya, keberadaan perempuan di dunia eksploitasi seksual komersial lebih banyak bukan karena kemauan sendiri, tetapi kondisi lingkungan sosial budaya di mana perempuan itu berasal sangat kuat mempengaruhi mereka terjun ke dunia eksploitasi sosial terutama untuk dikirim ke kota-kota besar.

\section{Faktor penegak hukum}

Inti dan arti penegakan hukum terletak pada kegiatan menyerasikan nilai-nilai yang terjabarkan di dalam kaidah-kaidah yang mantap dan mengejawantah dan sikap tindak sebagai rangkaian penjabaran nilai tahap akhir, untuk menciptakan, memelihara, dan mempertahankan kedamaian pergaulan hidup. Dalam arti sebenarnya penegak hukum berlaku sebagai orang yang bertindak untuk menjaga kemanan dan ketertiban.

\begin{abstract}
"Penegak hukum harus mengerti betul apa yang hendak dijaga dan dilindungi. Kadang, penegak hukum ada yang kurang informasi mengenai modus operandi pencari kerja ini, sehingga perlu dipahami kembali, dan saya yakin modus operandi mulai berkembang, jadi penegak hukum selain unit PPA juga diminta untuk melakukan identifikasi lebih jauh" (Informan F).
\end{abstract}

Pernyataan tersebut dapat diartikan jika para penegak hukum seyogianya mengatahui apa yang harus dilakukan untuk menjaga keamanan dan dapat mengayomi masyarakat. Informan mengaku masih ada petugas yang belum memahami modus operandi dalam bentuk agen pencari kerja, sehingga perlu dilakukan identifikasi lebih lanjut.

Hal ini kemudian dijadikan bahan untuk dinyatakan sebagai upaya perdagangan orang atau pengiriman pekerja secara ilegal. Setiap perilaku manusia yang didasari dengan keterbatasan atas pengetahuan tertentu, akan berdampak pada kesalahan untuk melakukan sesuatu dalam skala yang lebih besar. Kaidah-kaidah tersebut menjadi pedoman bagi perilaku atau sikap tindak yang dianggap pantas atau yang seharusnya. Perilaku atau sikap tindak tersebut bertujuan untuk menciptakan, memelihara dan mempertahankan kedamaian. Dapat juga dikatakan bahwa penegakan hukum dalam masyarakat berarti membicarakan daya kerja hukum dalam mengatur dan memaksa masyarakat untuk taat kepada hukum. Penegakan hukum tidak terjadi dalam masyarkat karena ketidakserasian antara lain nilai, kaidah, dan pola perilaku. Oleh karena itu, permasalahan dalam penegakan hukum terletak pada faktor-faktor yang mempengaruhi penegakan hukum itu sendiri.

\section{Simpulan}

Faktor yang melatarbelakangi terjadinya perdagangan anak yaitu faktor ekonomi, faktor lingkungan, faktor pendidikan faktor sosial budaya, ketidakadaan kesetaraan gender dan faktor penegak hukum. Perdagangan tenaga kerja sebagai sebuah tindak kejahatan, perlu penanganan yang lintas sektoral dan melibatkan semua instansi terkait, baik Departemen Tenaga Kerja, Kepolisian, Kejaksaan, Keimigrasian, Perhubungan dan sebagainya. Pola pelayanan satu atap dan menyederhanakan administrasi bagi para calon tenaga kerja yang akan bekerja keluar negeri, setidaknya akan mengurangi maraknya pencalonan tenaga kerja ilegal dan di bawah umur.

\section{Daftar Pustaka}

Abdullah D (2017) Perlindungan hukum terhadap korban trafficking anak dan perempuan. Al'Adl 9 (2): 231-243.

Crane PA \& Moreno M (2011) Human trafficking: what is the role of the health care provider? Journal of Applied Research on Children: Informing Policy for Children at Risk 2 (1):1-27. 
Daud BS \& Sopoyono E (2019) Penerapan sanksi pidana terhadap pelaku perdagangan manusia (human trafficking) di Indonesia. Jurnal Pembangunan Hukum Indonesia 1 (3): 352 - 365.

Makarao MT (2014) Pemberantasan Tindak Pidana Perdagangan Orang. Veritas 5(1): 1-27.

McClain NM \& Garrity SE (2011) Sex trafficking and the exploitation of adolescents. J Obstet Gynecol Neonatal Nurs 40 (2): 243-252.

Nashriana (2011) Perlindungan Hukum bagi Anak di Indonesia. Jakarta: Rajawali Pers.

Sanchez R \& Stark SW (2014) The hard turt about human trafficing. Nursing Management 45 (1): 1923.

Santoso T \& Zulfa EA (2005) Kriminologi. Jakarta: PT. RajaGrafindo Persada.

Soekanto S (1986) Pengantar Penelitian Hukum. Jakarta: UI Press.

Takariawan A \& Putri SA (2018) Perlindungan hukum terhadap korban human trafficking dalam perspektif Hak Asasi Manusia. Jurnal Hukum IUS QUIA IUSTUM, 2 (5): 237-255.

Reese - Weber M \& Smith DM. (2010). Outcomes of Child sexual abuse as predictors of laters sexual victimization. Journal of International Violence 26 (9):1899-1905.

Winterdyk J \& Reichel P (2010) Introduction to special issue: Human trafficking issuees and perspectives. European Journal of Criminology 7 (1): 5 - 10.

Wulandari C \& Wicaksono SS (2014) Tindak pidana perdagangan orang (human trafficking) khususnya terhadap perempuan dan anak: Suatu permasalahan dan penanganannya di Kota Semarang. Yustisia 90 (X): $15-26$.

Yin RK (2002) Studi Kasus: Desain dan Metode. Jakarta: PT Raja Grafindo Persada. 